\title{
Hydro power plants, an overview of the current types and technology
}

\author{
Štefan Tkáč \\ Technical University of Košice, Slovakia \\ Civil Engineering Faculty, Institute of Institute of Architectural Engineering \\ e-mail: stefan.tkac@tuke.sk
}

\begin{abstract}
Despite the long history of hydropower technology and rising number of system harvesting energy from alternative sources, the constant research within hydro power sector becoming increasingly important as the power from water was and still is the leading alternative source of green energy generation, capitalized not necessarily within micro-urban structures only. The advantages of hydro systems involve their relatively low acquisition cost against durability, the possibility of gaining energy independence, relatively high flexibility and adaptability for spatial conditions and energy demands of the end users. Nowadays micro hydro systems could capitalize head range starting at $100 \mathrm{~cm}$ and the efficiency of hydro systems in general ranges between $65-75 \%$ in micro and small applications climbing up to $96 \%$ in macro designs. It is mostly due to flexibility in applications, adaptability in combinations with other renewable energy systems and the ability to generate clean, stable, thus reliable energy that makes technical development the most vibrant and noticeable in the micro sphere.
\end{abstract}

Key words: hydro power, power plant, renewable resources, water

\section{Introduction}

Based on the last UNO reports there are 7.6 billions of people around the globe and this number is constantly rising. These increases in population rise along with trends of expanding urbanization (over 54\%) resulting in rapid industrialization especially in the undeveloped regions which requires higher energy demands.

Naturally country goes through several development stages of industrialization until its inhabitants mature enough to use proper technology to harvest energy in clean and renewable way by having the lowest possible impact on the local flora and fauna. In $21^{\text {st }}$ century the fast pace of local urbanization trends of Latin and South America, Asian, African and Indian regions eventuates industrialization processes that are many times seen skipping this natural development by applying the high-tech systems directly into individual dwellings of people who were literary growing crops few weeks ago. Teaching people how to use Renewable Energy Sources(RES) with $21^{\text {st }}$ century technology is thus a crucial issue for discussion and if 
meaningful it needs to be taught step by step. Hydro power is commonly known as one of the oldest way how to harvest energy of the nature and capitalize it further[1]. Thus studying and applying micro hydro power as decentralized RES is one of the ways how to make local people understand the current headings, energy demands and also insurance of the equitable rural and urban development in conjunction with plausible sustainable integration, hence expansion of cities without leaving the centralized energy sources in the hands of global corporations which taking advantage of rural development level and current state of art of its inhabitants. As a matter of fact the largest annual hydro power development happens exactly in previously mentioned regions on all levels from micro community actions in the form of rural applications via personal pico or micro hydro turbines up to large scale hydro power projects. Details could be observed in the Table no. 1 below.

Table 1: Installed capacities of countries leading in hydro power development

\begin{tabular}{|l|l|l|}
\hline Country & Added capacity in 2016 & $\begin{array}{l}\text { Overall installed capacity(IHA) } \\
\text { and World Energy Council }\end{array}$ \\
\hline $\begin{array}{l}\text { China - 13th five-year plan for } \\
\text { energy development2015 - 2020 }\end{array}$ & $\begin{array}{l}11.7 \mathrm{GW} / 3.7 \mathrm{GW} \text { of pumped } \\
\text { storage }\end{array}$ & $331,11 \mathrm{GW}$ \\
\hline Ecuador & $2 \mathrm{GW}$ & $4.409 \mathrm{GW}$ \\
\hline Ethiopia & $1.5 \mathrm{GW}$ & $3.813 \mathrm{GW}$ \\
\hline South Africa & $1.3 \mathrm{GW}$ & $3.573 \mathrm{GW}$ \\
\hline Vietnam & $1.1 \mathrm{GW}$ & $14.3 \mathrm{GW}$ \\
\hline Peru & $1 \mathrm{GW}$ & $3.82 \mathrm{GW}$ \\
\hline Switzerland & $1 \mathrm{GW}$ & $15,6 \mathrm{GW}[2]$ \\
\hline
\end{tabular}

What is more, 71\% of Earth's surface is covered by water. [3] The ocean currents or the wellknown hydrological cycle, water represents one of the most precious natural movements that hold the key to life on the planet and according to the recent research, water has been the component of the universe since its very beginning.

The bond between human and water is also quiet strong. Human is born in the amniotic sac composed mainly from water, hence the human ability to sense the water as the natural environment until the $3^{\text {rd }}$ year after birth. In average $65 \%$ of the human body is made of water, $73 \%$ if it comes to infant. Water element is the closest to human nature just as the growing tendencies, undoubtedly observable in urban context). Water should be definitely part of this natural process ("nature to human to urban") of environmental interaction.

The energy of water is basically transformed solar energy. From the overall solar energy delivered by the Sun to Earth, it accounts for only 0.4\% [4]. However, the technically feasible energy conversion of water into electrical power in comparison to the direct conversion of solar energy is much more effective, which makes this source of energy very interesting for mass application.

After the intensive efforts of International Hydropower Association (IHA) which opposed the World Commission on Dams (WCD) report from 2000 regarding challenge for large dams effectiveness and guidelines for the development of new dams, hydro power worldwide is experiencing an upsurge. The total installed capacity has grown by 39\% from 2005 to 2015, with an average growth rate of nearly $4 \%$ per year. [5] The total hydropower generation for the year 2016 is estimated at 4,102 TWh, the greatest contribution ever delivered from a renewable source. An estimated $31.5 \mathrm{GW}$ of hydropower capacity was put into operation, including pumped storage, bringing the world's total installed capacity to 1,246 GW. $6.4 \mathrm{GW}$ of pumped storage capacity came online, nearly twice the amount installed in 2015 while 
there is a further $20 \mathrm{GW}$ of pumped storage under construction globally. [6] As a mature technology, hydropower provides $\mathbf{1 6 , 4 \%}$ of global electricity production. [7] As to the energy storage the storage hydropower (including pumped storage, PS) represents between 96 - 99\% of the world's operational electricity storage with installed capacity over $162.2 \mathrm{GW}$. [8,9]

\section{Types of hydro power plants}

Water power plants in each particular country are built because of two purposes. Local and Nationwide. In case of local, each installation has some different purpose, tying to fill in the gap of specific mechanical or energy problem that occurs in the given area, e.g. water mill, water hammer, funicular, local railway for mine or wood. Alternatively, hydro power plant could help to generate hydrogen or support local power grid because of the current trends in transport transformation to electric and hybrid power hence the higher power demands and green energy limitations. Also it many times seen as a viable option for decentralized generation (DG approach).

On the other hand the nationwide purpose is completely different agenda and it is usually based on the country's hydrological system. For example, in Slovakia most of the hydro power plants are weir types, because of simple fact that overwhelming majority of the Slovak rivers spring in Slovakia thus their aquosity is either low or extremely volatile on the contrary Taiwanese hydro power plants are combination of predominantly cascade, diversion and large accumulation types because of the annual precipitation rate, typhoons or sudden droughts. What is more Taiwan is an island country thus it is quiet important to keep the fresh mountain water on surface as long as possible. Therefore hydro power plants have many times multifunctional character e.g. "Mă'ān" hydro power plant(馬鞍水力發電廠) on Fig. 1. below which except the electrical energy generation also incorporates retention basins further used for irrigation, drinking and industrial water supply. On the other hand Slovakian water structure "Selice" has regulation, navigation and electrical energy generation function [10].

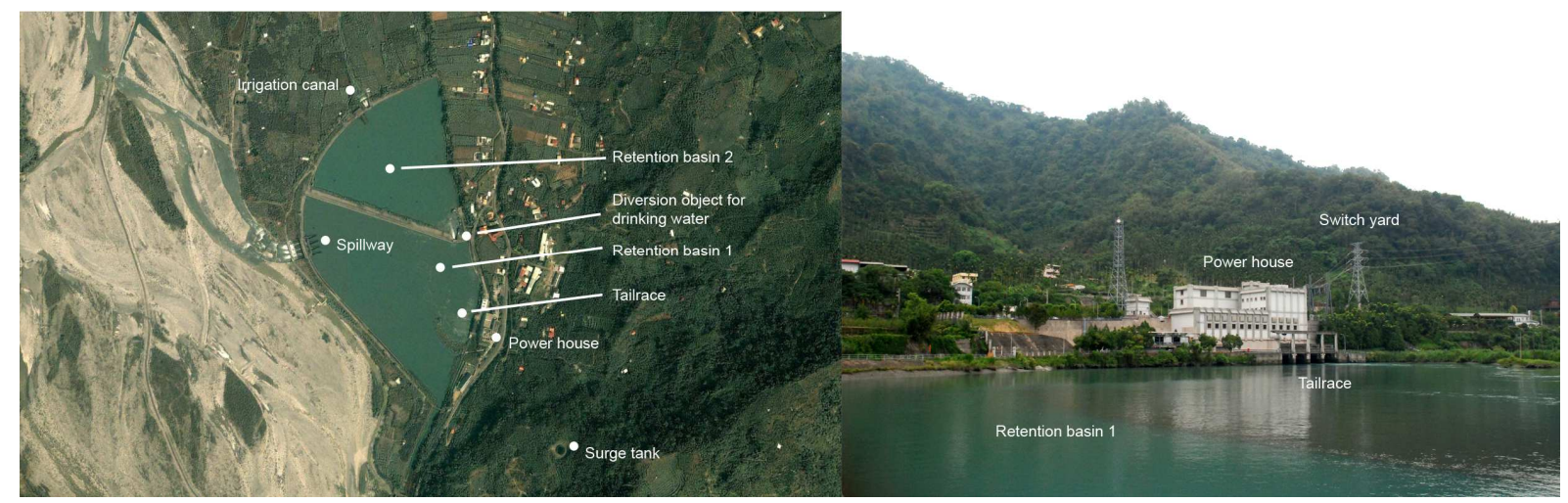

Figure 1: Mă'ān hydro power plant(馬鞍水力發電廠), located on Dàjiă river(大甲溪) in Taichung, northern Taiwan. (fig. source: Author 2015). 
Table 2: Division of Hydro power plants according to configuration.

\begin{tabular}{|l|l|}
\hline \multicolumn{2}{|l|}{ Large and medium types } \\
\hline Accumulation type & Using reservoir with dam or surging weir \\
\hline Pumped storage & Using two reservoirs \\
\hline Weir type & Using river regulation weir \\
\hline \multicolumn{2}{|l|}{ Small, Micro and Pico types } \\
\hline Weir type & $\begin{array}{l}\text { Using existing weir originally built for water level } \\
\text { regulation or newly built surging weir. }\end{array}$ \\
\hline Pumped storage & $\begin{array}{l}\text { Using two reservoirs or lake and water tank with } \\
\text { sufficient head. }\end{array}$ \\
\hline $\begin{array}{l}\text { Derivative or diversion types usually } \\
\text { called Run-of-River types ROR. }\end{array}$ & Using diversion weir or not using weir at all. \\
\hline 1. No pressured derivation & $\begin{array}{l}\text { Using diversion canal, side canal, adjusted river } \\
\text { arm or river bed. }\end{array}$ \\
\hline 2. Positive pressure derivation & Using penstock \\
\hline 3. Negative pressure derivation & Using siphon tube \\
\hline $\begin{array}{l}\text { 4. Combined derivation (No pressured } \\
\text { and positive pressure or No pressure and } \\
\text { negative pressure) }\end{array}$ & $\begin{array}{l}\text { Using diversion canal and then penstock or siphon } \\
\text { tube }\end{array}$ \\
\hline
\end{tabular}

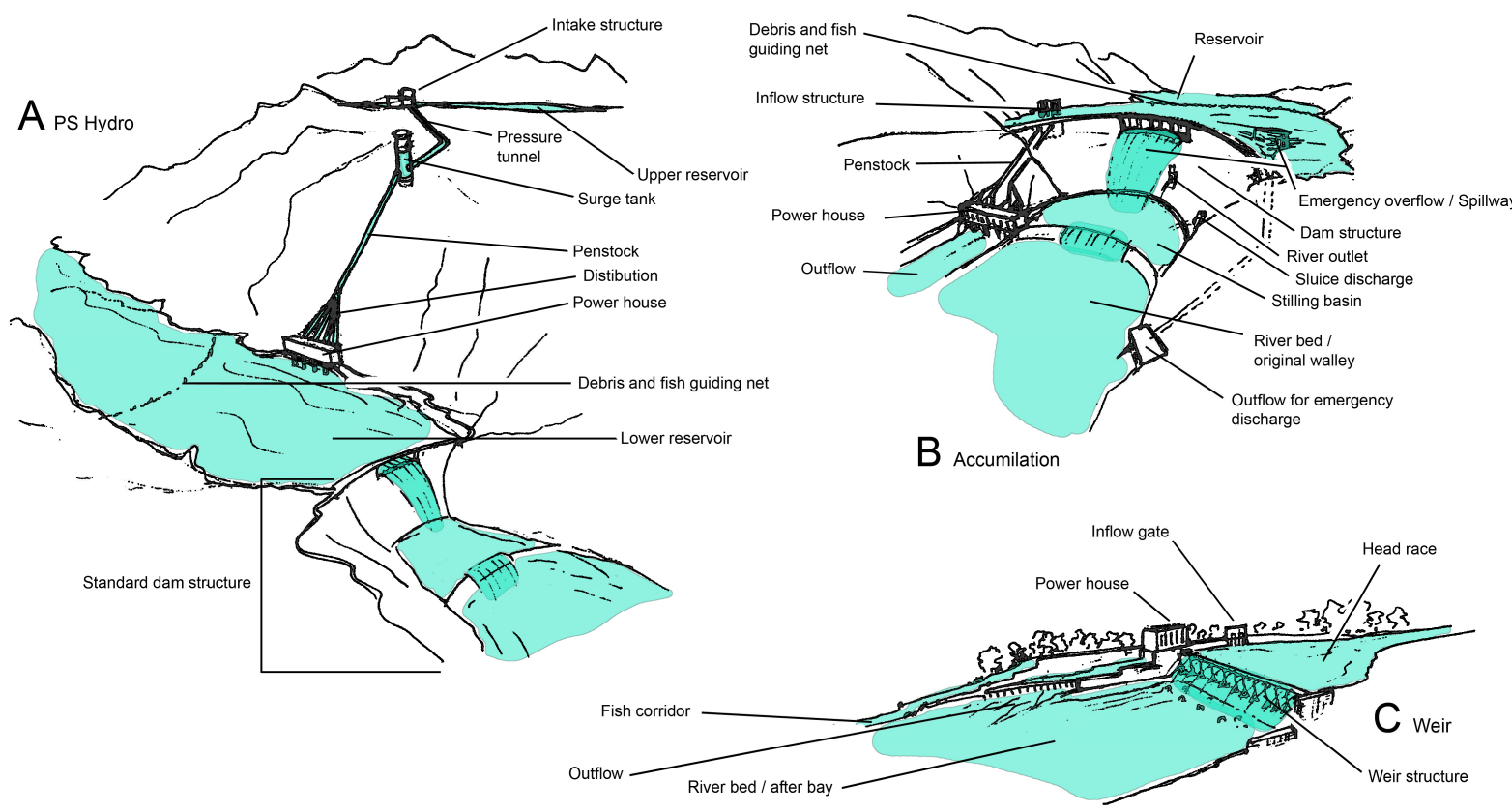

Figure 2: Classification of large and medium hydro power plants according to configuration from Table 2.: A-Pumped Storage type, B-Accumulation type and C-Weir type. (fig. source: Author 2018). 


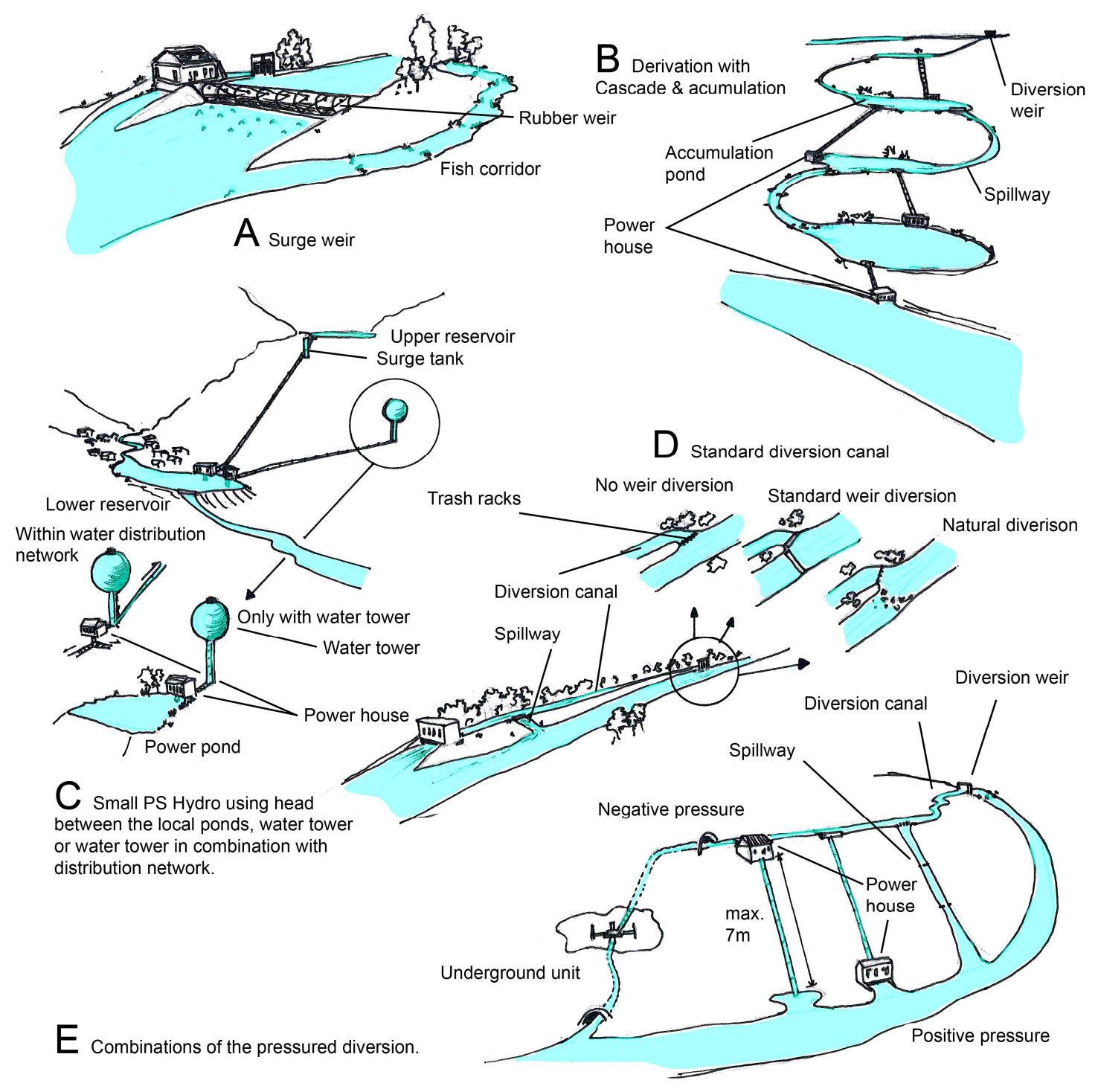

Figure 3: Classification of Small, Micro and Pico hydro power plants according to configuration from Table 2.: A-Standard weir type with rubber weir, B-Derivation including accumulation cascade, C-Small PS hydro with upper pond or water tower D-Standard diversion via diversion canal, E- Combination of no pressure with positive and negative pressure configuration. (fig. source: Author 2018).

Table 3: Classification of hydro power plants according to installed capacity.

\begin{tabular}{|l|l|}
\hline Large/Very large & $>100 \mathrm{MW} / 0,5 \mathrm{GW}$ \\
\hline Medium & $25-100 \mathrm{MW}$ \\
\hline Small & $1-25 \mathrm{MW}$ \\
\hline Mini & $100 \mathrm{~kW}-1 \mathrm{MW}$ \\
\hline Micro & $5-100 \mathrm{~kW}$ \\
\hline Pico & $<5 \mathrm{~kW}$ \\
\hline
\end{tabular}


There are any ways how to further set typology of hydro power plants, in this paper we use division based on Table no. 2 where hydro power plants are divided according to their capacity and configuration.

Based on the installed capacity listed in Table no.3, hydro power plants could be divided from very tiny private pico, micro and mini systems which capacity usually does not exceeds $1000 \mathrm{kWs}$, then small or medium installations with capacity measured in MWs up to large or very large water works which capacity is set mostly in GWs. For example within Visegrad area we can sort out large installation like Slovak "Vodné dielo Gabčíkovo"(720MW), "Žilina"(72MW) or "Orava"(21.75MW), but naturally there are even larger installations like Russian "Sayano-Shushenskaya"(6400MW) power plant, Brazilian "Itaipu"(Table no.4) on Paraná River which currently holds the world's record on annual production or according to the installed capacity the largest installation among all located in Chinese, Hubei on Yangtze River known as "Three Gorges Dam"(Table no.4).

There are no major questions regarding the magnitude of large scale installations accept possible ecological risks, however if it comes to small hydro power plants(SHP), the installed capacity is many times a point for debates as it has not been fixed yet. For instance in Italy it represents 3MW, in Germany $5 \mathrm{MW}$, in Poland and Hungary 5MW, in Czech Republic, Slovakia, Austria and Philippines 10MW, however Taiwan has 20MW, India 25MW, USA 30MW and below, China and Canada has both 50MW [11]). For all that the maximum capacity of $10 \mathrm{MW}$ is commonly recognized according to ESHA (European Small Hydropower Association) [12], Small Hydropower World portal[11] developed by ICSHP (International Center on Small Hydro Power)[13] and UNIDO (United Nations Industrial Development Organization)[14] and will be further used in reference to the SHP.

Table 4: Classification of the 2 largest hydro power plants in the world

\begin{tabular}{|l|l|l|l|l|l|}
\hline $\begin{array}{l}\text { Name and } \\
\text { the Year of } \\
\text { commission }\end{array}$ & Country & No. of units & River & $\begin{array}{l}\text { Installed } \\
\text { capacity }\end{array}$ & $\begin{array}{l}\text { Annual } \\
\text { production }\end{array}$ \\
\hline $\begin{array}{l}\text { Three } \\
\text { Gorges } \\
\text { Dam 2003 }\end{array}$ & $\begin{array}{l}\text { Hubei province, } \\
\text { China }\end{array}$ & $\begin{array}{l}34 \mathrm{x} \\
\text { Francis Type }\end{array}$ & $\begin{array}{l}\text { Yangtze } \\
\text { River }\end{array}$ & $22,5 \mathrm{GW}$ & $98.8 \mathrm{TWh}(2014)$ \\
\hline $\begin{array}{l}\text { Itaipu Dam } \\
1984\end{array}$ & $\begin{array}{l}\text { Brazil and } \\
\text { Paraguay }\end{array}$ & $\begin{array}{l}20 \mathrm{x} \\
\text { Francis Type }\end{array}$ & $\begin{array}{l}\text { Paraná } \\
\text { River }\end{array}$ & $14 \mathrm{GW}$ & $\begin{array}{l}89.5 \mathrm{TWh}(2015) \\
103.1 \mathrm{TWh}(2016)\end{array}$ \\
\hline
\end{tabular}

\section{Types of turbines}

Hydro turbines are considered as a heart of hydro power plants, it almost all the time represents the highest investment in the entire project. After the electric engine hydro turbine got the highest efficiency, plus the fact that it is the most applied RES system, even slightest possibility to higher this effectiveness could make major differences.

The fact that hydro turbines are already mastered technology comes from the vast history of applications that will not be discussed in detail due to large volume of information, however it is important to mentioned that water wheel as the "proto-machine" using water power was one of the technical inventions that anticipated the $1^{\text {st }}$ Industrial Revolution. As a matter of fact the power of water was among the early types of energy human masters to be the engine of his ideas along with all its variations like horizontal or vertical axis wheel from Hellenic Greece, further derived water mill, gristmill, vertical shaft Norse mill, Cornwall stamp mill, 
sugar and steel mill, hullers, Portuguese tide mills, irrigation water rising wheels, Roman reversed overshot wheels for mines(mentioned in Marcus Vitruvius Pollio's treatise De architectura / Ten Books on Architecture) or hydro turbine which could be find in roman ruins in Tunisia where it serves most likely as a mill.
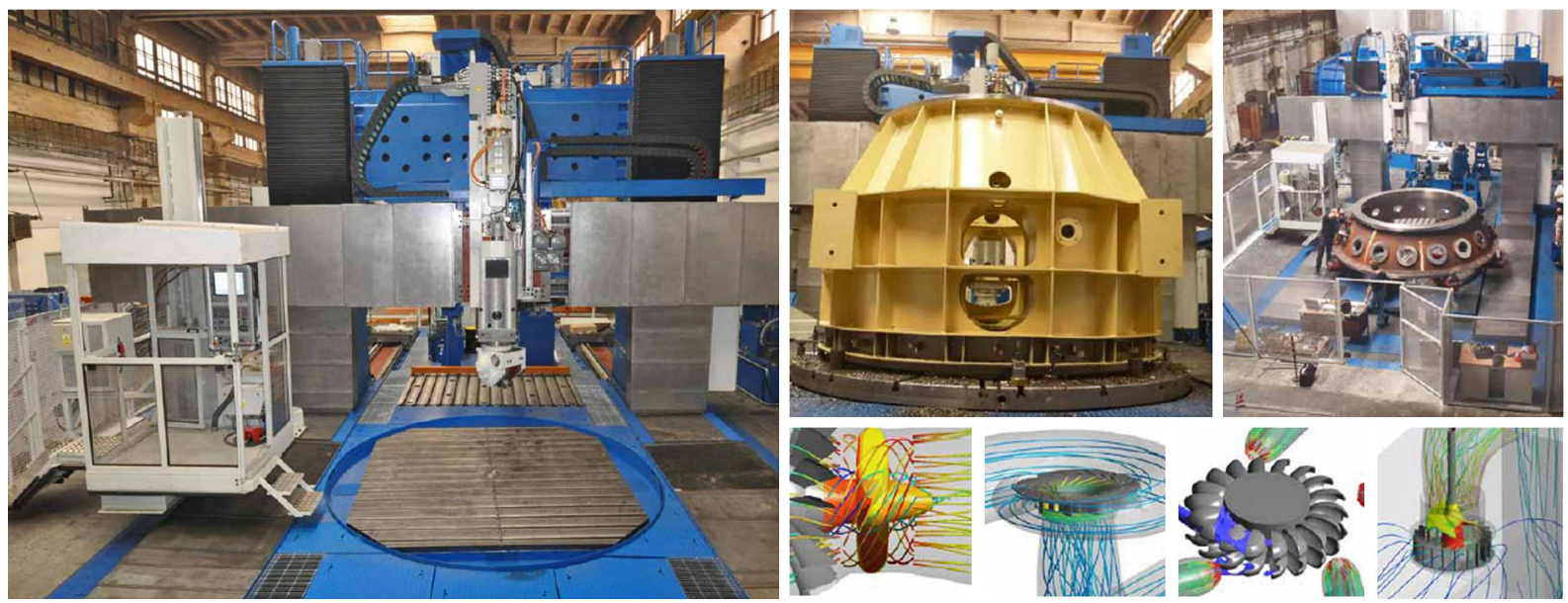

Figure 4: Hydro turbine manufacturing process and CFD software simulation. (fig. source: Mavel hydro turbine technology brochure 2018[15]).

Nowadays hydro turbines are subject for high precision manufacturing based on ISO's standards attained by CAD drawing softwares e.g. Autodesk Inventor. The feasibility of design is later tested by Computational Fluid Dynamics CFD e.g. Autodesk CFD - Fluid Flow $\&$ Flow. Further manufacturing processes use CNC technologies, usually multi axis milling machine pictured on Fig. 4. Turbine runners and blades are special parts which are either milled, casting or forging. In case of $R \& D$ a digital manufacturing technologies might be applied. All these processes result in precise calibration and balance for securing ideal working surfaces hence the highest energy conversion efficiency of the modern water turbine.

\subsection{Turbines division according to environment and applied medium}

There is vast number of hydro system which application depends on the physical conditions of the given environment (development site) mostly represented by water discharge versus net head in contrast to desired demands.

Generally the overwhelming majority of applied micro hydro systems broadly applied in SHP using concept with diversion weir followed by inflow pipe or penstock leading directly to the power house [16]. This configuration could use high or low head and low or high flow volume and is largely connected with the application of all types of micro turbines from slower reaction types with high torque like Francis or Kaplan in bulb, PIT, "S" and "Z" (Saxo) turbine configuration or high pressured and speed, but lower torque impulse types like single, double-nozzle "Pelton" turbine, alternatively single-nozzle "Turgo" turbine or OssbergerBanki-Crossflow turbine. All depends on given environmental conditions. Of course large and multipurpose installations are more complex thus they could not be mass produces. 


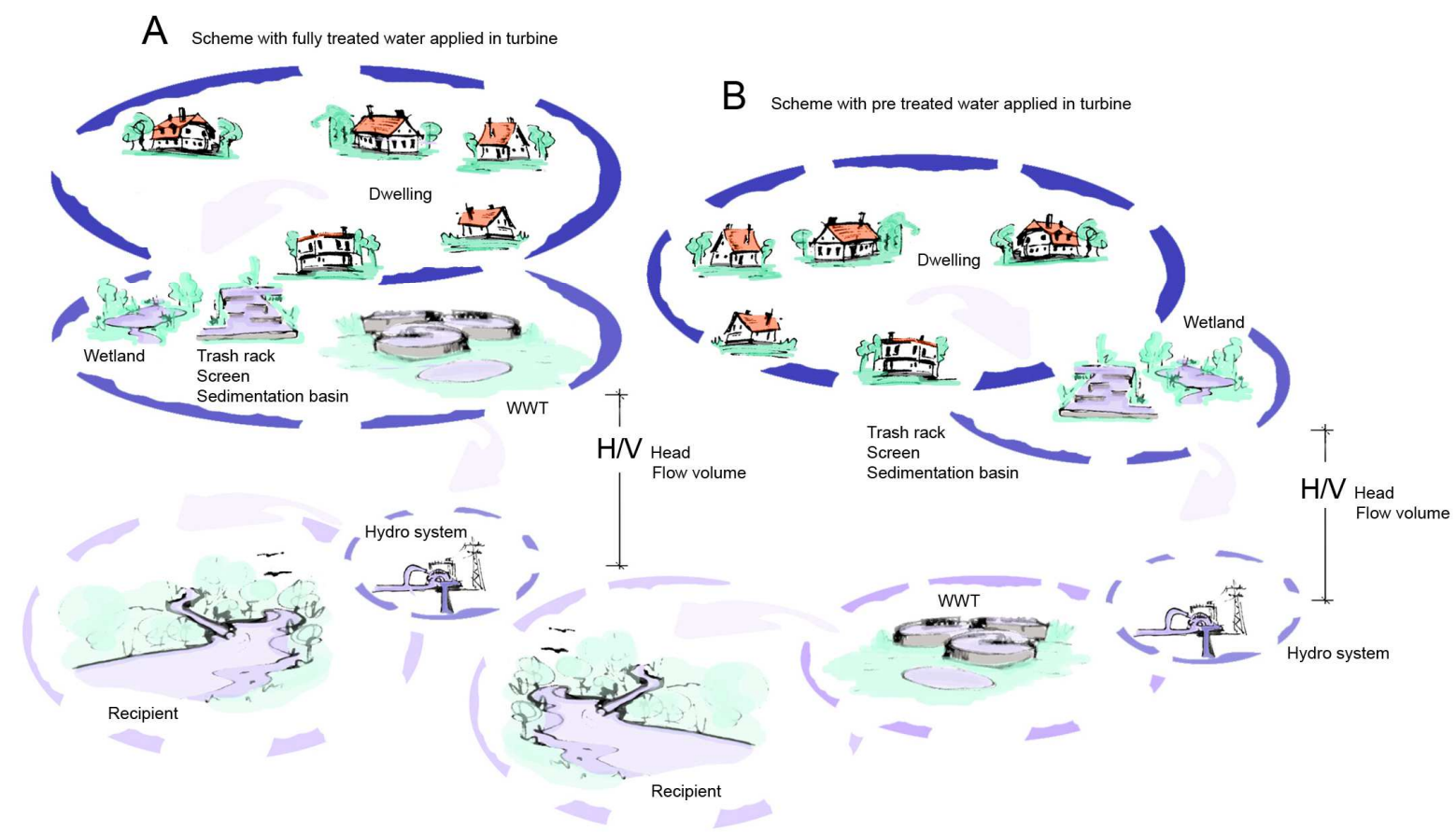

Figure 5: Two common schemes of hydro power systems harvesting energy from waste water treatment process in case sufficient flow volume and head is present. Scheme A the water that enters turbines is fully treated by combination of sedimentation and separation systems and WWTP itself, hence the turbine works with clean water that returns back to the biothope. However in scheme B the waste water is just acquitted from solid and large particles, but not the chemicals that are treated in WWTP after they went through the hydro power system.

(fig. source: Author 2018).

Another condition for hydro systems typology is the construction which is specified by the type of the intended medium. There is hard water and salty water causing sedimentation of the minerals (water stone, limestone) on the surface of turbine blades and within pipelines, which might results in change of the hydrodynamic profile of the turbine blades and smaller the flow volume. Further in case of wetlands, sewers and waste Water treatment plants(WWTP) applications where the hydro turbine is exposed to the most aggressive environment consists of various rigid debris, chemical combinations of acid and alkaline water e.g. $\mathrm{H}_{2} \mathrm{~S}-\mathrm{Hydrogen}$ sulfide which causes serious corrosion and has the capability of destroying carbon steel within weeks. The mentioned salts or solid particles can also pose a threat to the turbine blades degradation which may results in unbalance of the entire runner.

Generally hydro turbines applied in this kind of conditions could be divided into systems applied before the treatment processes and those placed after. The various combinations could be observed in the Fig. 5. Both systems no matter applied in front or rear of the WWTP are subject for special anticorrosion treatment like highly valuable Duplex stainless steel and adequate ceramic coating, alternatively if more cost-effective solution with less efficiency is acceptable an application of a simple systems like reversed Archimedes screws or water wheels are suggested. 
Ultimately the water with high portion of sand and small rocks - sediment-laden water, causing erosive and abrasive wear visible especially on turbine blades which results in efficiency reduction and extensively shorten the overall life span of the turbine.

The last but not least there is new generation of hydro turbines applied in specific installations and working under versatile conditions like reversible types not only applicable in PS hydro systems, but also in wave, ocean current or tidal energy harvesting technology which has been in research for the past decades. Interesting is also application in osmotic installations where turbines could also operate reversibly. These and many more just prove the versatility of hydro turbine as a viable RES system and secure energy back up technology.

\subsection{Turbines division according to the working principle}

Whether hydro turbines are Pico, Micro, Mini, Small, Large or Very system they could be further divided according to the energy conversion into impulse, reaction or driven by medium properties.

\subsubsection{According to the energy conversion}

In case of impulse turbines represented by commonly used standard Pelton, Ossberger-BankiCrossflow types or Pico and Micro installations represented by Turgo and various water jet types the technological configuration applies mostly high heads and low flow volumes. Although these are ideal conditions for impulse turbines, sometimes the natural conditions and economics requires various adjustments like multi jet Pelton or dual Pelton runner due to lower head, but higher flow volumes, better performance or simply larger generator to be turned. Technologically speaking impulse turbines using water impulses, water jet that is constantly interrupted by individual blades of the runner which causes vibrations that are usually eliminated by flywheel or mentioned multi jet, especially in large installations.

Reaction turbines like Francis, Kaplan or micro Propeller types on the other hand are much slower with higher torque and are placed directly into the moving water mass which presses on turbine blades(action) and causing runner to turn(reaction). Since they are literary working inside the medium, they require higher flow volumes hence they are many times used in previously mentioned current or tidal power plants. Reaction turbines are more versatile, better regulated via guide vanes, flaps or adjustable blades, they are sophisticated and therefore more expensive. On the other hand, since they are mixed pressure systems they are also subject for cavitations risk. These types of turbines can perfectly react to the fluctuations of the grid or unstable river conditions hence their installation in reversible form within PS hydro complexes.

The medium properties turbines are mostly research types and represent development sphere. Largely they are reaction bladeless types that using physical properties of the water e.g. viscosity, non compressibility, boundary layer, cohesion, centrifugal force etc. Good examples are MUMT Micro Urban Multipurpose Turbine Mark I from 2012[17] which is still in research, or already commercially available SETUR turbine from 1991[18]. If it comes to bladeless impulse turbines one of the old examples is Nicola Tesla's centripetal flow TESLA turbine [19] patented in 1913. 


\subsubsection{According to the head}

According to the head water turbines could be divided into three categories namely High, Low and Ultra Low Head (ULH). ULH could be found in micro applications usually with low water discharge e.g.: small irrigation canal or local village stream, but in larger scales the discharge could rise, e.g.: larger canal if available or simply wider river bed. Canal applications are literary direct stream applications without changing the original course of the river hence their name Run-of-the-river(ROR) systems. Good examples are Japan, Philippine, Vietnam, Cambodia and Laos irrigation canal power plants or Italian adjustable hydroelectric wheel from Ener.Cat.Italia, Bonciani placed on Canavese Canal in Torino or in Marano sul panaro in Modena further Canadian Instream hydrokinetic turbine or smaller Japanese Ibasei Kappa generator[15]. Many SHP are also called ROR due to low head with mostly high discharge e.g.: previously mentioned wide riverbed. Nowadays ROR SHPs implement rubber dam due to possible flood risk and bio corridor for natural fish bypass hence their environmental impact is mostly considered as positive rather than negative [20].

\section{Applications}

Fig. 2-3 shows several configurations how to design hydro power plant including the PS hydro in conventional way that could be seen in various manuals. Micro hydro systems got same principles. Current development of hydro power is focused on three main areas:

The first one is how to integrate hydro energy with the rest of the RES systems hereinafter the so called hydro energy integration or hybrid RES power plant [21]. As mentioned several times before hydro energy is the most stable from all the RES therefore integration with e.g. solar panels, wind turbines or even biogas or bio mass is constantly under research. They could work as a supplementary sources during dry season with less water, flood where water discharge could not be used with most turbines, winter season when generation is limited due to ice or simply as a source covering hydro power plant's own consumption.

Another variation of integration is energy storage which is a more sophisticated and mostly refers to volatile RES application to cover the pumping phase solving two problems at once. First storing volatile and fluctuating electrical energy generated from wind farms or solar panels and secondly discharge it as a stable electrical current with no harm to the grid. This system is called the Variable Speed Hydro Generator. The further combinations includes hydrogen generation or air compression, pumping water into old unused water towers, caves, mines or reuse potential of the existing pipelines like pictured on Fig. 3 part C. At the end PS hydro technology is always about creating energy potential between two reservoirs which is sometimes subject for ecology and landscape questions thus there is a search for alternatives like using ocean water in case of Hawaii or underwater spheres capitalizing vertical pressure variation like in case of Storing Energy at Sea(StEnSea) project from German Hochtief [22].

The last researched area is focused on types of energy harvesting, which means types of turbines and their conversion principles. Generally the sphere of micro hydro systems is the most visible. The goal is to higher the efficiency, lower the head, flow volumes and smaller the technology. The smart applications based on sets of variations calculated via mathematical methods e.g. genetic algorithms has as a result optimization of the power plant operation [23]. This kind of smart power houses could estimate the potential of river by its previous behavior 
and correlate it with expected grid demands. This is also part of the hydro power development focuses.

\section{Conclusion}

We are verging to the time where term mega polis would be more appropriate in reference to the urban areas. If it comes to sustainable city growth a decentralized or so called distribution energy model looks like one of the viable option. Despite the constant clash of nuclear vs. nuclear free policy the RES are natural form of energy harvesting with little or no pollution. It is due to vast history that hydro energy is a mature technology quiet close to the imagination of large spectrum of the population. Also it is the leading RES and energy storage system that could be incorporated into various combinations with the rest of the commercially available RES technology therefore R\&D on hydro power systems in the mean of energy storage and energy transformation especially within micro urban areas should be the primary focus in sustainable development of our future communities.

"Innovation has been always applied at small scales first. If it comes to hydro-energy generation, it is exactly the sphere of micro hydro systems in which all the novelty is brought up". (Author duing designing MUMT turbine)

\section{Acknowledgements}

The Author wishes to thank first assoc. prof. Ing. Zuzana Vranayová PhD., prof. Ing. Peter Horbaj, PhD. and prof. M.S. Sz-Chwun "John" Hwang PhD. for the constant encouragement, support and advisement during post doctoral studies. The presented paper is component of the project VEGA no.: 1/0202/15 - "Sustainable and Safe Water Management in Buildings of the 3rd Millennium", ERASMUS+ KA107 and Post doctor Visegrad-Taiwan Scholarship.

\section{References}

[1] PAISH, O. (2002). Small hydro power: technology and current status. Renewable and Sustainable Energy Reviews Vol. 6, (no. 6), p. 537-556 ISSN: 1364-0321

[2] World Energy Council. (2018). Hydropower in Switzerland. Retrieved date of January 15 ${ }^{\text {th }}$, 2018, from https://www.worldenergy.org/data/resources/country/switzerland/hydropower/

[3] Fakulta elektrotechniky a informatiky FEI STU Ilkovičova 3, 81219 Bratislava. (2018). Obnovitel'né zdroje energie - Vodná energia. Retrieved date of access January $14^{\text {th }}$, 2018, from http://www.oze.stuba.sk/oze/vodna-energia/

[4] DUŠIČKA, P. HODÁK, T. (1998). Small water power plants. In Editors of the book (Eds.), Book title (184pp.). Bratislava: Jaga group.

[5] World Energy Council. (2016). World Energy Resources Hydropower | 2016. Retrieved date of access January $15^{\text {th }}$, 2018, from https://www.worldenergy.org/wp-content/uploads/2017/03/W EResources_Hydropower_2016.pdf

[6] International Hydro Power Association - IHA. (2017). Hydropower status report 2017. Retrieved date of access January $15^{\text {th }}$, 2018, from https://www.hydropower.org/sites/default/file s/publications-docs/2017\%20Hydropower\%20Sta tus\%20Report.pdf 
[7] REN21. 2017. (2017). Renewables 2017 Global Status Report. (Paris: REN21. ISBN 978-39818107-6-9 Retrieved date of access January 13 ${ }^{\text {th }}$, 2018, from http://www.ren21.net/wpcontent/uploads/2017/06/17-8399_GSR_2017_Full_Report_0621_Op t.pdf

[8] International Energy Agency. (2012). Technology Roadmap Hydropower. (@ OECD/IEA, 2012. Retrieved date of access January $14^{\text {th }}$, 2018, from https://www.iea.org/publications/freepublica tions/publication/2012_Hydropower_Roadmap.pdf

[9] DOE Global Energy Storage Database Office of Electricity Delivery \& Energy Reliability. (Copyright () 2018 Sandia Corporation). DOE Global Energy Storage Database. Retrieved date of January $15^{\text {th }}, 2018$, from https://www.energystorageexchange.org/projects/data_visualization

[10] PAVLIKOVÁ, A., MOŽIEŠIK, L. (2016). Optimization of the operation of the selice water structure on the Váh River with regard to navigational safety. Pollack Periodica Vol. 11, no. 3 (no.2), p.93-104ISSN:1788-1994

[11] UNIDO \& ICSHP (2013) Small hydropower world. Retrieved date of January $10^{\text {th }}$, 2018, from http://www.smallhydroworld.org/

[12] ESHA (2013) Small hydropower world. Retrieved date of January $10^{\text {th }}$ ，2018, from https://ec.europa.eu/energy/intelligent/projects/en/projects/shp-streammap

[13] International Center on Small Hydro Power (ICSHP) (2018) International Center on Small Hydro Power (ICSHP). Retrieved date of January $13^{\text {th }}$, 2018, from http://www.inshp.org/about .asp

[14] United Nations Industrial Development Organization. UNIDO. (2018) International Center on Small Hydro Power (ICSHP) . Retrieved date of January 13 ${ }^{\text {th }}$, 2018, from http://www.unido.org/

[15] Mavel, a.s. - 2015. (2015). Mavel company brochure. Retrieved date of January $15^{\text {th }}$, 2018, from http://mavel.cz/wp-content/uploads/2016/05/Brochure_2016_electronic.pdf

[16] MISHRA, S., SINGAL, S.K., KHATOD, D.K. (2011). Optimal installation of small hydropower plant-A review. Renewable and Sustainable Energy Reviews Vol. 15, (no. 8), p. 3862-3869 ISSN: 1364-0321

[17] TKÁČ, Š. (2017). The power of water within micro urban structures (144pp). Beau Bassin: LAP Lambert Academic Publishing. ISBN: 978-620-2-07422-3

[18] MECHANIKA Králuv Dvùr s.r.o.. (2005). Turbine SETUR. Retrieved date of access, January $5^{\text {th }}, 2018$, from http://www.mechanikakd.cz/gbturbina.html

[19] N. Tesla, "Tesla Turbine" U.S. Patent1,061,206, issued May 6, 1913.

[20] ZELEŇÁKOVÁ, M. et al. (2018). Environmental Impact of Small Hydro Power Plant-A Case Study. Environments: an Open Access Journal by MDPI Vol. 5, (no. 1), p. 1-10 ISSN: 20763298

[21] Smart Hydro Power (2018). Hybrid power plant with solar panels and river turbine as optimal solution for decentralized electrification in colombia. Retrieved date of access January $13^{\text {th }}$, 2018, from http://www.smart-hydro.de/hybrid-power-plant-with-solar-panels-and-river-turbineas-optimal-solution-for-decentralized-electrification-in-colombia/

[22] HOCHTIEF Aktiengesellschaft. (2018). Light from the seabed. Retrieved date of access January $10^{\text {th }}, 2018$, from https://www.hochtief.com/hochtief_en/320.jhtml?id=17.

[23] KINCZER, T., ŠULEK, P. (2016). The impact of genetic algorithm parameters on the optimization of hydro-thermal coordination. Pollack Periodica Vol. 11, (no. 2), p. 113-123 ISSN:1788-1994 